\title{
SUPERBOHATER PRL-U NA PRZYKŁADZIE FILMU ANDRZEJA KONDRATIUKA HYDROZAGADKA
}

TOMASZ KuŹMICZ

Uniwersytet Kardynała Stefana Wyszyńskiego w Warszawie Cardinal Stefan Wyszyński University in Warsaw (Poland) meursault@o2.pl

PRL-owska kultura masowa, zarówno film, jak i powieść milicyjna czy komiksy, pełna jest bohaterów, którzy charakteryzują się niespotykaną w prawdziwym życiu kumulacją rozwiniętych w najwyższym stopniu możliwości fizycznych i umysłowych. Rozwiązują niezwykle skomplikowane zagadki, bez trudu radzą sobie z pokonaniem agresorów i zawsze wiedzą, co w danej chwili powiedzieć. W dodatku stoją na straży ładu i porządku publicznego, skutecznie przeciwstawiając się złu.

Z tak ogólnego opisu wynika, że polscy superbohaterowie nie różnią się od postaci wykreowanych w tym samym czasie (lub nieco wcześniej) przez twórców zagranicznych, zwłaszcza amerykańskich i angielskich, którzy dostarczali odbiorcom potężnych porcji rozrywki, opowiadając o kolejnych przygodach takich bohaterów, jak Superman, Batman czy James Bond. Wystarczy jednak nawet krótka, ale wnikliwa lektura Kapitana Żbika, dowolnego opowiadania z serii Ewa wzywa 07 lub obejrzenie kilku polskich filmów kryminalnych i szpiegowskich z lat 50. i 60. XX wieku, by zauważyć, że czas, w którym dzieła te powstały, panujący wówczas ustrój i wymogi cenzury odcisnęły na nich wyraźne piętno. Przepis na polskiego superbohatera, ale i na otoczenie, w którym on działa, musiał więc być szczególny, tym bardziej że z założenia powinien on przeciwstawiać się wzorom zachodnim. Na czym jednak te różnice miałyby polegać? I jaka konfiguracja „superbohaterskich" cech zbliżała postacie do oficjalnie obowiązującego ideału, a jaki ich dobór decydował o negatywnym zabarwieniu, czyniąc z nich uosobienie zła? Poszukiwanie odpowiedzi na te pytania jest głównym celem niniejszego artykułu. Jego zakres wyznaczą ponadto między innymi takie zagadnienia, jak: superbohater jako mit współczesności, manichejski podział świata 
i wizja walki dobra ze złem obecna w twórczości wykorzystującej postaci superbohaterów, czy też propagandowy obraz Polski jako socjalistycznego raju oraz Europy zachodniej i Ameryki jako źródła wszelkiego zła.

Analiza superbohatera PRL-u przeprowadzona zostanie na przykładzie Asa, protagonisty Hydrozagadki, filmu telewizyjnego z 1970 roku w reżyserii Andrzeja Kondratiuka. Jest to postać o tyle szczególna, że jej pierwowzorami byli amerykańscy superbohaterowie. As jednak, poza tym że naśladuje i parodiuje „kolegów” zza oceanu, jest jednocześnie doskonałym reprezentantem "polskiego supermana”. Twórcy obdarzyli go bowiem wieloma cechami bezpośrednio nawiązującymi do innych postaci rodzimej kultury masowej, między innymi komiksowego kapitana Żbika oraz Stanisława Kolickiego, czyli agenta J-23 z niezwykle popularnego serialu Stawka większa niż życie. Co więcej, As to chodząca encyklopedia powszechnie znanych w latach 60. propagandowych haseł. Co prawda nagromadzenie takich odwołań sprawia, że postać ta jest mocno przerysowana, a tym samym groteskowa, ale za to dostarcza tak wielu schematów, zgodnie z którymi kształtowano wówczas idealny wizerunek funkcjonariusza, agenta czy po prostu obywatela, że można by obdzielić nimi kilku albo nawet kilkunastu „poważnych” superbohaterów.

\section{ZACHÓD ZAWSZE PODEJRZANY}

As to nadobywatel w krzywym zwierciadle. Z jednej strony, ze względu na podobieństwo do zachodnich superbohaterów, jest postacią zupełnie w polskim kinie wyjątkową, $\mathrm{z}$ drugiej - skupiającą w sobie wszystkie niezbędne cechy socjalistycznego herosa. W tym nadmiarze As - inaczej niż kapitan Sowa, a zwłaszcza kapitan Żbik czy Hans Kloss - nieustannie przypomina odbiorcy, że jest jedynie częścią wykreowanego świata. Nie postacią „,z krwi i kości”, a znaczącym ideogramem, „bytem zmitologizowanym, personifikacją cnoty lub całego szeregu różnych cnót. Jako ideogram, a nie postać, ukazuje się zaś w całej krasie swej umowności - przerostu znakowości nad realizmem"1. Różnica ta może jednak służyć uwypukleniu podobieństw, ponieważ parodia, niczym szkło powiększające, poprawia czytelność zastosowanych schematów i ułatwia ich demaskowanie.

${ }^{1}$ J. Szyłak, Komiks: świat przerysowany, Gdańsk 1998, s. 38. 
Jednym ze stałych elementów PRL-owskiej propagandy był wyraźny podział świata na Wschód i Zachód, przy czym podział ten był nie tylko geograficzny i polityczny, ale również moralny. W komiksowej serii o kapitanie Żbiku najniebezpieczniejsi przestępcy, intryganci na ogromną skalę, zawsze pochodzą z Zachodu, głównie z Republiki Federalnej Niemiec. To stamtąd płynie strumień nielegalnych pieniędzy, dzięki którym mafiozi albo szaleńcy usiłują budować w Polsce sieć powiązań, by ułatwić sobie dokonywanie spektakularnych i dochodowych przestępstw:

zleceniodawca występuje zawsze w tle, nie bierze zatem udziału w „mokrej robocie”, zostawiając jej wykonanie oraz ryzyko, jakie się z nim wiąże, polskim kryminalistom. Tę nadrzędną rolę Niemców można odczytać jako przykład kapitalistycznych stosunków, które wdrażane są nielegalnie [...] na gruncie demokracji ludowej. Zresztą zapłata, jaką oferują Polakom za wykonanie zlecenia, jest iście „imperialistyczna”. Najczęściej są to dolary oraz paszport umożliwiający ucieczkę na Zachód ${ }^{2}$.

Komiksowe zeszyty pouczały więc, jak należy odbierać zachodnich sąsiadów. Skoro Niemiec proponuje współpracę polskiemu naukowcowi, a gdy ten odmawia, zleca jego zabójstwo (Wzywam 0-21), inny z kolei, syn byłego esesmana, każe ukraść ikonę, w której spodziewa się znaleźć coś jeszcze cenniejszego (Tajemnica ikony), a są to tylko pierwsze z brzegu przykłady odbiorca dostaje czytelny sygnał, że z RFN-u (bo to zawsze RFN, nigdy NRD) pochodzi wszelkie zło, którego należy się strzec albo które należy ścigać i skutecznie eliminować:

Strona zachodnioniemiecka uosabia [...] III Rzeszę oraz wszelkie negatywne wartości, jakie się jej przypisuje. RFN jest tu kontynuatorem faszystowskiej polityki zagranicznej, która ma na celu między innymi: okradanie państwa polskiego zarówno z dóbr materialnych, jak i kulturowych, wykradanie cennych informacji oraz wynalazków będących osiągnięciami polskich inżynierów ${ }^{3}$.

2 M. Wycinek, Kapitan Żbik - fenomen propagandy PRL-u (1967-1982), [w:] Popkomunizm, red. M. Bogusławska, Z. Grębecka, Kraków 2010, s. 119-120.

3 Ibidem, s. 119. 
Dlatego wzorowy obywatel socjalistycznego państwa musi zawsze stać po przeciwnej stronie barykady niż ci, którzy dali się zwieść urokom kapitalistycznego świata - włączając w to wszystko, z czym ów świat powinien się kojarzyć, a więc przepych i bogactwo, nadmierne (i źle pojęte) umiłowanie wolności oraz daleko posuniętą demoralizację. „Karty, wódka, plugawe dowcipy i łobuzerskie wybryki. [...] Plereza i baczki - to legitymacja zachodniej kultury"4, z której czerpią bikiniarze, czyli - zgodnie z oficjalnym rozpoznaniem - chuligani, na których jest tylko jeden sposób: „trzeba ich otoczyć powszechną pogardą i pędzić precz"

Taki obraz „zapożyczeń” z kultury zachodniej obowiązuje także bohaterów Hydrozagadki. Dobrzy stoją na straży swojskich wartości (nauka, dobro społeczne, przepisy BHP), a źli mają powiązania za żelazną kurtyną i są przesiąknięci fałszywymi ideałami zachodniego świata. „Czytam Timesa i Epocę. Pijam tylko Ballantine'sa. Palę - Winstony. Dla ciebie mam Wintermansy, zagraniczne czekoladowe cygara" - wylicza pan Jurek, epatujący konsumpcyjnym stylem życia podrywacz. Podobną filozofię wyznaje doktor Plama. „Cóż, moja matka była manicurzystką i pedicurzystką. On - jedynak, rozpieszczany przez ojca, bankiera, wysłany do Heidelbergu, w kasynach i lupanarach zachodniej Europy swój geniusz rozmieniał na drobne. Na przykład cyrkówki kąpał w szampanie. Hulaka, [...] jak to się dzisiaj popularnie mówi - playboy" - charakteryzuje go kolega z czasów studenckich, profesor Milczarek.

\section{GROTESKOWE WCIELENIE SUPERMANA}

Przeciwieństwem demonicznego doktora Plamy oraz oddającego się przyjemnościom doczesnym pana Jurka jest nieskazitelny As:

Kawaler, nie pije, nie pali, szkolę ukończył z oceną celującą, sportowiec amator, finalista biegów przełajowych, przechodził szczepienia ochronne, w dzieciństwie nie chorował na świnkę, koleżeński, stały w uczuciach, punktualny, obowiązkowy, nienaganny pracownik uśmiechnięty na co dzień, wszechstronnie aktywny, sprawny fizycznie i umysłowo. Tyle pozytywnych

${ }^{4}$ Operator was podpatrzyt (1953), „Polska Kronika Filmowa” 17/53, WFDiF.

${ }^{5}$ Ibidem. 
cech w jednym człowieku daje niepospolitą moc i energię. Dlatego nasz bohater jest fenomenem natury! ${ }^{6}$

To wzór socjalistycznego obywatela, który dzięki kumulacji tak starannie dobranych zalet posiadł nadludzkie umiejętności. Ale - jak zauważa Przemysław Dudziński - „można spekulować, że nadczłowieczeństwo Asa potencjalnie dostępne jest dla wszystkich, jest on bowiem końcowym produktem systemu kształtowania idealnego człowieka socjalizmu, ostatnim etapem marksistowskiej wizji historii człowieka"7.

As bez trudu pokonuje prawo ciążenia czy przepycha pociąg z podoczepianymi wagonami. Na każdą okazję ma również odpowiednią sentencję rodem z agitacyjnej gazetki ściennej czy propagandowej czytanki („Ważne są przepisy BHP, zwłaszcza na kolei”). Jako nadobywatel, As jest uosobieniem socjalistycznego komunału. W myśl zasady, że alkohol szkodzi zdrowiu, on i abstynencja to jedno - niczym dwie strony medalu, które nie mogą istnieć oddzielnie (alkohol może go unicestwić, tak samo jak kryptonit mógł zabić amerykańskiego Supermana). Chodzi jednak o coś więcej niż zdroworozsądkowe przestrzeganie behapowskich zaleceń. Walczak został Asem - otrzymał najwyższą rangę wśród agentów - dzięki idealnemu dostosowaniu się do socjalistycznego wzoru. Nie może pozwolić sobie na odstępstwo od zasad, bo bez nieustannego wcielania ich w życie pozostałby zwykłym kreślarzem jednego $\mathrm{z}$ warszawskich biur. Zachowuje więc czujność, by w każdej chwili móc właściwie zareagować. Zresztą innym poleca to samo: „Padł pan ofiarą niecnego spisku, [...] na przyszłość radzę zachować czujność”. Co jednak najważniejsze, zawsze staje w obronie ofiary i wymierza sprawiedliwość oprawcy. Nie waha się nawet zaryzykować życia i w obliczu nadchodzącej katastrofy taranuje podwodną centralę doktora Plamy. Pamięta przy tym, by założyć kask - najistotniejszy, bo osłaniający głowę element odzieży ochronnej.

Jednak na początku lat 70., kiedy Hydrozagadka po raz pierwszy pojawiła się na ekranach, grany przez Józefa Nowaka "Superman znad Wisły”

${ }^{6}$ Fragment scenariusza przytoczony za: M. Łuczak, Wniebowzięci, czyli jak to się robi „Hydrozagadkę”, Warszawa 2004, s. 53.

7 P. Dudziński, Geneza Asa - superbohatera Polski Ludowej. „Hydrozagadka” Andrzeja Kondratiuka jako kontranaliza społeczeństwa PRL-u, [w:] Superbohater. Mitologia wspótczesności (antologia pokonferencyjna), „Maska”, Kraków 2012, s. 87. 
zanim cokolwiek zrobił czy powiedział, już był skojarzony z obowiązującym wówczas wzorem bohatera. Jego twarz, dziś już dużo mniej rozpoznawalna, była wówczas powszechnie znana, i to właśnie z socrealistycznych produkcji, takich jak Pamiątka z celulozy czy Pod gwiazda frygijska Jerzego Kawalerowicza. Ale i w rzeczywistości Nowak „nie odbiegał od parodiowanego przez Hydrozagadkę ideału obywatela: członek PZPR i Ochotniczej Rezerwy Milicji Obywatelskiej, kawaler Brązowego Medalu za usługi dla obronności kraju"8. Już po zagraniu w Hydrozagadce wzbogacił swoją kolekcję „trofeów” między innymi o złoty pierścień zdobyty na Festiwalu Piosenki Żołnierskiej oraz Medal 30-lecia Polski Ludowej przyznawany za co najmniej piętnastoletnią pracę zawodową i zaangażowanie w działalność społeczno-polityczną.

To, że akurat tak zasłużony aktor jak Nowak wcielił się w rolę superagenta, było świadomym zabiegiem reżysera:

Hydrozagadka bowiem miała być przede wszystkim parodią kina socrealistycznego. Tym śmieszniejszą i bardziej absurdalną, iż w równym stopniu stanowiła zręczny pastisz amerykańskiego komiksu heroicznego. [...] I tu, i tam nie wolno było okazywać jakiegokolwiek współczucia „czarnym charakterom” oraz zabraniano przedstawiania „policjantów, sędziów, urzędników rządowych w sposób mogący podważyć szacunek do władzy”".

Poza twarzą, która mocno wiązała polskiego superbohatera $\mathrm{z}$ rodzimą rzeczywistością, jego wizerunek jest produktem importowanym z USA, a raczej świadomie nieudolną kopią amerykańskiego pierwowzoru.

Na co dzień As ukrywa się pod postacią Walczaka - skromnego kreślarza pracującego $\mathrm{w}$ jednym $\mathrm{z}$ warszawskich biur urbanistycznych. W tym czasie w Polsce Ludowej jest to zawód cieszący się dużo większą powagą niż dziennikarstwo, które uprawiał Klark Kent, kiedy nie miał do wykonania żadnych zadań jako Superman:

I w tym miejscu film zdecydowanie parodiuje rzeczywistość mu współczesną. Bowiem u początku lat siedemdziesiątych wzorem obywatela i bohaterem propagandy nie byli już członkowie sojuszu robotniczo-chłopskiego, lecz

8 Ibidem, s. 89.

9 Ibidem, s. 51. 
właśnie inteligencja techniczna średniego szczebla, ludzie tacy jak Walczak i inżynier Karwowski - bohater oddającego chyba najlepiej klimat dekady serialu Czterdziestolatek ${ }^{10}$.

Natomiast dziennikarze, cieszący się ogromną popularnością i zaufaniem w USA, w Warszawie nie mają w tym czasie żadnego znaczenia. Propozycję panny Joli, by w sprawie tajemniczego znikania wody napisać do gazety („Już oni załatwią”), jeden z biurowych kolegów kwituje krótko: „To nic nie da, [...] tą sprawą powinien zająć się As".

Pomijając odmienne profesje, sytuacja obu bohaterów jest niemal identyczna, i to zarówno w życiu osobistym, jak i „na służbie”. Obaj, bez trykotów, za to w okularach z grubymi oprawkami, gubią się pośród tysięcy podobnych im obywateli. Ponadto uwikłani są w podobną sytuacje romansową. Nie da się również nie zauważyć pokrewieństwa wizualnego: i jeden, i drugi - w swym superbohaterskim wcieleniu - nosi obcisły trykot z emblematem na piersi i peleryną, pas oraz wysokie buty. Ale logo Asa wygląda jak wycięte przez niezbyt ambitnego ucznia na lekcji ZPT (Zajęcia Praktyczno-Techniczne). Tak samo peleryna - „jest krótka, sięgająca mu tylko do pasa, plącze się raczej groteskowo, zamiast majestatycznie powiewać jako surogat flagi"11.

Jest jednak i coś, czego nie ma Superman, a posiada As. Polski superbohater został dodatkowo wyposażony w raportówkę - taką samą, jakiej używali PRL-owscy milicjanci. Ten wymowny gadżet przytroczony na zbyt długim pasku obija się bohaterowi o kolana, co potęguje karykaturalny wizerunek Asa, ale zbliża go też do służb mundurowych, przypominając, jakie wartości parodiuje w ten sposób przedstawiony bohater.

Groteskowy charakter postaci uzupełniają ostentacyjnie nieefektowne sceny, w których As korzysta ze swoich supermocy - na przykład puszczony od tyłu skok z wysokości czy widoczny na ekranie moment lądowania, który ma komunikować, że przed chwilą As był w powietrzu.

Sekwencje te, zamiast przekonywać swym realizmem, epatują nieudolnością, która współgrając ze strojem i sposobem wypowiadania się, niesie

${ }^{10}$ Ibidem, s. 88-89.

11 Ibidem, s. 88 . 
dodatkowe znaczenia. Jak pisze Dudziński: „reżyser niedostatki techniczne włączył tu po prostu w burleskowy dyskurs filmu"12.

\section{POLSKIE METROPOLIS}

W Hydrozagadce fikcyjne miasto, w którym działa amerykański Superman, zastępuje supernowoczesna Warszawa, ukazana ,jako cywilizacja rozwoju, postępu i szczytów nowoczesności”'13. Już po pierwszym, krótkim, panoramicznym ujęciu wiadomo, że akcja rozgrywa się w niezwykle ruchliwej metropolii o szerokich ulicach i strzelistych wieżowcach. Te ostatnie stanowią także tło w scenach dialogowych. Bohaterowie znajdują się w obszernych biurach, w których przed nadmiernym nasłonecznieniem chronią ich żaluzje, albo na zewnątrz, pod parasolami, gdzie chłodzą się, jedząc lody. Jak zauważa Tomasz Rakowski: „ich życie to rodzaj peerelowskiego high-life toczącego się przy stolikach, na świeżym powietrzu"14.

Od pierwszych sekund filmu owej majestatyczności towarzyszy ironiczny ton, na wstępie już sygnalizowany przez ścieżkę dźwiękową (twórcy wykorzystali powojenną piosenkę Warszawski dzień, którą piętnaście lat wcześniej Państwowy Zespół Pieśni i Tańca sławił warszawian poświęcających się dla odbudowy stolicy). ,Jest to jeden z pierwszych sygnałów, że satyryczny dyskurs Hydrozagadki odnosić się będzie do dwóch różnych okresów historii PRL-u: żywej jeszcze w pamięci epoki socrealizmu i współczesności początków gierkowskiej »drugiej Polski»"'15.

Perłą tego ultranowoczesnego świata jest instytut - ogromny, przeszklony, pełen zakamarków i długich korytarzy gmach. Jego pracownicy, wysłani po Walczaka i przypominający raczej przedstawicieli tajnych służb niż naukowców, poruszają się citroenem DS, ówczesnym cudem techniki, symbolem luksusu i nowoczesności. Ubrani są w czarne garnitury, a jeden z nich, najbardziej aktywny, nosi przyciemniane okulary. Poza groźną wieloznacznością tych trzech - jak ich określa profesor Milczarek - „współpracowników”:

\footnotetext{
12 Ibidem.

13 T. Rakowski, Rozwiązanie „Hydrozagadki”, [w:] Popkomunizm, op. cit., s. 188.

14 Ibidem.

15 P. Dudziński, op. cit., s. 88.
} 
Atmosfera w laboratorium [...] napawa entuzjazmem. Widać tam pracujących bez ustanku nad „procesem wodnym” naukowców, zawzięcie pipetujących, miareczkujących, oglądających kolby z wodnistą substancją. Miasto staje się w tym obrazie rodzajem dobrze naoliwionej maszyny i jest to oczywiście typowy obraz spełnionego socjalizmu $[\ldots]^{16}$.

Maszyna ta nie działa jednak jak należy. Na kilku osiedlach zaczyna brakować wody, zwłaszcza na wyższych piętrach. W PRL-u podobne trudności nie miały w sobie nic z surrealistycznego koszmaru. Były raczej nieodłącznym elementem wielkomiejskiego życia, co - jak zauważa Rakowski - wynikało z lokowania osiedli z „kompleksami straszliwych bloków-mrówkowców” na ówczesnych obrzeżach miast, za to w pobliżu wielkich ośrodków przemysłowych:

Otóż przemysł ciężki - huta, walcownia, wielkie piece i kombinaty do swego życia i funkcjonowania potrzebują, nie mniej, ni więcej, tylko ogromnych ilości wody (!) - przemysł zużywa ją w trakcie procesu wytapiania stali, chłodzi rozżarzone żużle i ogniwa, pochłania wszelkie jej zapasy - zapasy wody pitnej, wyczerpuje wodę ze zbiorników retencyjnych. [...] Woda w bloku w tamtych czasach znakomicie to wiedziano - mogła zostać odłączona w którymkolwiek momencie, woda "gdzieś” znikała i wtedy zaczynało się piekło ${ }^{17}$.

Ale w supernowoczesnej Warszawie z Hydrozagadki, w tej idealnie skonstruowanej maszynie do mieszkania, pracy i wypoczynku usterka nie wynika z jakichkolwiek nieprzemyślanych decyzji czy niedoróbek. Lekkomyślni mieszkańcy, prześcigając się w domysłach, błądzą po omacku - sądzą, że winni są hydraulicy albo że pompy, filtry czy hydrofory nie działają tak, jak powinny.

Tymczasem brak wody w kranach jest wynikiem imperialistycznego spisku określonych kół (maharadży Kawuru sprzymierzonego z doktorem Plamą), władze nie ponoszą więc za taki stan żadnej odpowiedzialności. Podobny schemat był wówczas na porządku dziennym. Jeśli nie zagraniczni wrogowie Polski Ludowej, to tzw. obiektywne trudności sprawiały, że zimą nie starczało prądu, w sklepach nie było mięsa, tramwaje i pociągi jeździły niepunktualnie,

16 T. Rakowski, op. cit., s. 188.

17 Ibidem, s. 191. 
a klucze nie pasowały do zamków drzwi w nowo budowanych mieszkaniach spółdzielczych ${ }^{18}$.

„Przyczyny zła należy szukać u źródeł, inna metoda to absurd” - zauważa profesor Milczarek. Nawet mózg elektronowy nie podołał zadaniu i po wprowadzeniu danych „wypluł wielki znak zapytania”. Z taką zagadką może poradzić sobie tylko superagent. „As jawi się więc jako strażnik rozwoju i potęgi technologii, które w micie nowoczesności wciąż grożą wydostaniem się spod kontroli czy przejściem w ręce złego demiurga" ${ }^{\prime 19}$.

\section{WALKA DOBRA ZE ZŁEM}

W prostym, wyraźnie podzielonym świecie Hydrozagadki przeciwnikiem pracującego dla dobra ogółu superagenta jest demoniczny doktor Plama genialny, ale zdeprawowany zachodnim stylem życia przestępca, który nie cofnie się przed niczym, pod warunkiem że będzie to wystarczająco wyrafinowane. Co prawda Plama godzi się na zasztyletowanie marynarza (bo nie lubi gadatliwych), a nawet sam organizuje w remizie potańcówkę, podczas której Liliput ma się go pozbyć, kiedy jednak maharadża proponuje, by ściąć albo otruć Asa, doktor stanowczo odmawia: „Pan wybaczy, książę, to są prymitywne metody, nie wytrzymują próby czasu”. Podobną odpowiedź otrzymuje książę na pytanie, czy Plama nie zechciałby uśmiercić Liliputa: "Jestem człowiekiem interesu i nie lubię mokrej roboty".

Plama, niczym niewzruszony romantyczny dandys, w obliczu śmiertelnego niebezpieczeństwa podziwia okoliczności, w jakich ma dojść do ostatecznego starcia $\mathrm{z}$ superagentem: „Dramat rozegra się w oprawie rozszalałych żywiołów. To lubię. Zadziwiający synchron”. „Pan jest diabłem” - stwierdza maharadża. „Przede wszystkim estetą” - odpowiada mu na to Plama. To właśnie ów niepokojący zmysł piękna i dramaturgii, pozbawiony jednocześnie podbudowy etycznej, każe mu zauważyć, że „mord w remizie nie ma żadnych walorów widowiskowych".

Rozrywka, obok mamony, przed którą zepsuty geniusz chyli czoła, jest jedną z podstawowych wartości, najwyżej cenionych i poszukiwanych zarówno przez doktora, jak i maharadżę. To odwrócony kodeks Asa, który dla odmiany ceni sobie „dobro społeczne i spokój publiczny”, za to zupełnie

${ }_{18}$ M. Łuczak, op. cit., s. 56.

19 Ibidem, s. 188. 
nie interesuje go zysk. Jest więc nieprzekupny, o czym informuje maharadżę doktor Plama. „Czy to jest Batman?” - pyta książę. „Gorzej, stosując nomenklaturę międzynarodową - Superman. Jest bardzo groźny” - słyszy w odpowiedzi.

Różnica między tymi bohaterami jest bardzo wymowna. Batman jest zwykłym człowiekiem stosującym różne wynalazki techniczne, natomiast Superman posiada nadludzkie moce. W tym przypadku nie to jest jednak najważniejsze. Batman działa z osobistych pobudek, jest mścicielem i ściga zabójców, którzy pozbawili życia jego rodziców, a niejako przy okazji tylko wymierza sprawiedliwość w innych sprawach. Natomiast Superman:

jest od niego szlachetniejszy. [...] Jego przybrani rodzice, państwo Kent, wpoili mu wielki szacunek dla tradycyjnych amerykańskich wartości: pracy, rodziny, prawa i porządku. Walczy więc o realizację tych wszystkich ważnych zasad $\mathrm{w}$ gigantycznym modelowym amerykańskim mieście Metropolis, wykorzystując wszystkie swoje nadprzyrodzone zdolności. Podobny system wartości - lecz właściwy wzorowemu obywatelowi socjalistycznego państwa, który przestrzega wszelkich przepisów, nawet BHP - cechuje Asa, pijącego wyłącznie oranżadę z bąbelkami i uznającego alkohol za największą truciznę $e^{20}$.

Obaj - Superman i As - stoją na straży ładu publicznego i tylko on ich interesuje. Każdy z nich „jest piękny, skromny i uczynny; jego życie poświęcone jest walce $z$ siłami zła, a policja ma w nim niestrudzonego sprzymierzeńca”21. Zwykli przestępcy to jednak zbyt mało, by superbohater musiał korzystać z pełni swoich możliwości. W pojedynku z Asem godnym przeciwnikiem okazuje się doktor Plama, pozbawiony skrupułów geniusz. O jego szerokich horyzontach świadczy przede wszystkim szalony plan odparowywania wody na skalę totalną. Plama zamierza przetransportować podgrzane do temperatury wrzenia i zamienione w parę jezioro do pustynnego Kawuru przy pomocy stosu atomowego. Jest przy tym tak przebiegły, że korzysta $\mathrm{z}$ rad zapowiadającego pogodę prezentera Wicherka, który nie mając o niczym pojęcia (a w związku z tym nie żądając za to żadnych pieniędzy), bierze udział w machinacjach szwarccharakteru. „Chmury, które nadpłynęły nad

20 Ibidem, s. 52.

21 U. Eco, Apokaliptycy i dostosowani, tłum. P. Salwa, Warszawa 2010, s. 325. 
pański kraj, należy skroplić. W tym celu instalujemy na pustyni sieć balonów na uwięzi. Każdy balon dźwiga lodówkę. Z oziębionej chmury tworzy się deszcz" - objaśnia Plama finansującemu operację maharadży, a kiedy książę chce poznać szczegóły, dostaje od doktora szkolny podręcznik: „Fizyka dla klasy siódmej. To jest genialne w swojej prostocie. Co za umysł. Pascal i Machiavelli w jednej osobie. Pan jest geniuszem" - stwierdza maharadża w przypływie entuzjazmu i podpisuje kontrakt, rezygnując z dogłębnej analizy dokumentów.

Ale nie tylko wspólnik od szemranych interesów poznaje się na geniuszu charyzmatycznego doktora Plamy. Także profesor Milczarek przyznaje, że Plama to niezwykle groźny przeciwnik. Opowiadając o czasach studenckich, wypomina mu hulaszczy tryb życia, po czym stwierdza: „Studia jednak ukończył z wyróżnieniem. Bezwzględnie inteligentny. Cóż, byłem wtedy młody, fascynował mnie, zazdrościłem mu, dziś ścigam przestępcę" - wyrzuca $\mathrm{z}$ siebie profesor, wygłaszając $\mathrm{w}$ ten sposób pouczającą przypowieść. Jasno z niej wynika, że podpatrzony na zachodzie styl życia to prosta droga do występku, a nawet zbrodni. Z kolei cierpliwa praca i podporządkowanie się słusznej idei to sposób na prawdziwą karierę naukową (i nie tylko, bo opowieść profesora Milczarka ma wartość uniwersalną) oraz, ostatecznie, triumf nad fałszywym bohaterem, który żyje wystawnie, ale marnie kończy. „Te dwa życiorysy mają kolosalną wartość dydaktyczną, zwłaszcza dla młodzieży" - podsumowuje As.

\section{DOBRO ZAWSZE ZWYCIĘŻA}

Rozważania profesora Milczarka prowadzą do odkrycia, że doktor Plama nie jest tylko czarnym charakterem, którego wyeliminowanie raz na zawsze przywróci ład i porządek w zaburzonym chwilowo socjalistycznym raju: „Swoją drogą, ten Plama zrealizował moją ideę, tylko w drugą stronę. To bardzo interesujące z metafizycznego punktu widzenia. Plus przyciąga minus. Negatyw ma swój pozytyw. Czarne i białe. Dobro przeciwstawia się złu”. Jak zauważa Maciej Łuczak:

Dobro i zło są - mówiąc językiem filozoficznym - kategoriami ontologicznymi. Gdy genialny, niezwyciężony, będący ucieleśnieniem wszystkich cnót As nie będzie miał żadnych przeciwników, stanie się znowu zwyczajnym kreślarzem Janem Walczakiem. Młodzież nie będzie miała pozytywnych 
i negatywnych bohaterów, straci moralne busole, a cały świat pozbawiony aksjologicznych wskazówek pogrąży się w totalnym chaosie ${ }^{22}$.

Dlatego doktor Plama jako uosobienie złych mocy może - a nawet musi być pokonany, ale tylko w ramach danej opowieści. Jego plan zagroził doskonale funkcjonującemu miastu - zdarza się tak nawet w najlepszym ze światów. Ład został jednak przywrócony, bo kryzys, skoro już nastąpił, musiał być - oczywiście po stosownej porcji perypetii - wcześniej czy później zażegnany. Ostatecznie zatriumfowało dobro - zgodnie z zasadą konstruowania powieści pocieszycielskiej, o której tak pisze Umberto Eco:

Nie można ujawniać kryzysu, jeśli następnie nie zaproponuje się rozwiązania, nie można wzbudzać oburzenia czytelnika na widok plag społecznych, jeśli następnie nie spowoduje się interwencji czynnika uzdrawiającego i jeżeli nie pomści się, wraz z ofiarami, skonfundowanego odbiorcy. Powieść staje się w takim wypadku machiną gratyfikacyjną, ponieważ gratyfikacja musi nastąpić jeszcze przed zakończeniem powieści i nie może być nigdy powierzona swobodnej decyzji czytelnika (jak czyni to powieść problemowa, głęboko „rewolucyjna”) 23 .

Doktor i maharadża zostali pokonani, nie zamierzają jednak przejść reedukacji i stać się dobrymi ludźmi, jak Liliput i marynarz. Ważne, by As, niepokonany strażnik ładu i porządku, pozostał czujny i zawsze gotowy do walki z niespodziewanie uaktywniającym się złem, tym bardziej że czasu na wytchnienie nigdy nie ma zbyt wiele. $Z$ tego nieustannego ścierania się przeciwstawnych pierwiastków, ale i z obowiązkowego triumfu dobra, doskonale zdają sobie sprawę czarne charaktery Hydrozagadki - doktor Plama i maharadża. Po eksplozji, do jakiej doszło przy zderzeniu Asa z bunkrem podwodnej centrali, obaj przestępcy ledwie uchodzą z życiem. „Tym razem się nie udało, ale następnym razem...?” - pyta Plama. „Też się nie uda” odpowiada ze śmiechem maharadża.

Ta wymiana zdań wyklucza jakiekolwiek wątpliwości - bohaterowie są jedynie znakami, elementami mitycznej opowieści o odwiecznej walce

22 M. Łuczak, op. cit., s. 55.

23 U. Eco, Superman w literaturze masowej, tłum. J. Ugniewska, Kraków 2008, s. $21-22$. 
dobra ze złem. Widz - podobnie jak czytelnik komiksów, o którym pisze Jerzy Szyłak - ma:

możliwość obcowania ze sferą cudu - opatrzoną cudzysłowem, opowiedzianą $\mathrm{z}$ dystansem, ale przedstawioną $\mathrm{w}$ sytuacji, $\mathrm{w}$ której prawdziwy mit wywołuje jedynie wzruszenie ramion. Kulturze wysokiej, zdominowanej przez egzystencjalny pesymizm, poczucie absurdu życia i świata, komiks [w tym przypadku film - przyp. T.K.] przeciwstawiał [...] obrazki, na których świat miał sens, co prawda naiwny, ale naiwny w sposób świadomy i wzięty w cudzysłów przerysowania, które umożliwiało zarówno zdystansowanie się do takiej wizji, jak i znalezienie alibi dla zainteresowania podobnymi historiami ${ }^{24}$.

W przypadku Hydrozagadki wspomniany przez Szyłaka cudzysłów został niejako przez twórców filmu podwojony. Na pierwszym poziomie sugeruje go uproszczona, superbohaterska konwencja, w której nie ma miejsca na skomplikowane osobowości i niejasne moralnie sytuacje. Na drugim - ten prosty świat jest dodatkowo przerysowany, bowiem mit supermana „przepuszczono” przez ostrze satyry i groteski, które w równym stopniu wymierzone zostało w PRL-owski schemat bohatera, co w przejętą z Zachodu konwencję superbohaterską.

\section{ZAKOŃCZENIE}

Jak wskazuje przeprowadzona wyżej analiza, polski bohater (socjalistyczny) ma inną świadomość i wyznaje inne wartości niż jego amerykański odpowiednik. Tak samo jednak poradzi sobie w każdej sytuacji, czy to wykorzystując siłę i spryt, czy błyskotliwą inteligencję. On także będzie stał na straży ładu i porządku publicznego. Ale uosabiając oficjalny ideał obywatela jednego z krajów bloku wschodniego, zyska szczególny rys odróżniający go od swoich odpowiedników zza żelaznej kurtyny. To konieczne, gdyż jego zadaniem jest obrona systemu, który przez cenzorów i propagandę przeciwstawiany jest zachodniemu chaosowi, złu, korupcji i konsumpcyjnemu stylowi życia. W takim świecie pieniądze, komfort, wyroby luksusowe i wycieczki zagraniczne (chyba że do krajów socjalistycznych) zawsze są podejrzane,

24 J. Szyłak, op. cit., s. 40. 
i to raczej zbrodniarz, złodziej lub szpieg będzie korzystał z podobnych dobrodziejstw, zaś superobywatel, skromny i świadomy pokus, które mogą go przywieść jedynie do zguby, pozostanie czujny i nieczuły na podszepty fałszywych imperialistycznych ideałów.

Polski superbohater nie splami się, jak Batman, osobistymi pobudkami i nie będzie szukał sprawiedliwości, by się mścić na oprawcach - nie byłby wtedy superbohaterem. Nie będzie też dbał o wysokość wynagrodzenia, bo energię do pracy znajdzie w niej samej i w poczuciu dobrze wypełnionego obowiązku.

Na tle zachodniej kultury masowej drugiej połowy XX wieku superbohater PRL-u pozostaje zjawiskiem szczególnym - dziś już, z punktu widzenia młodego odbiorcy, niemal egzotycznym - ściśle powiązanym z systemem, który upadł w roku 1989, i towarzyszącą mu ideologią. Jest więc przede wszystkim świadectwem epoki, ale nadal pozostaje „żywym” bohaterem, którego widownia wciąż odkrywa na nowo, inaczej tylko rozkładając akcenty przy dekodowaniu znaczeń.

\section{Bibliografia}

Przemysław Dudziński, Geneza Asa - superbohatera Polski Ludowej. „Hydrozagadka” Andrzeja Kondratiuka jako kontranaliza społeczeństwa $P R L-u$, [w:] Superbohater. Mitologia wspótczesności (antologia pokonferencyjna), „Maska”, Kraków 2012.

Umberto Eco, Apokaliptycy i dostosowani, tłum. P. Salwa, W.A.B., Warszawa 2010. Umberto Eco, Superman w literaturze masowej, tłum. J. Ugniewska, Znak, Kraków 2008.

Maciej Łuczak, Wniebowzięci, czyli jak to się robi „Hydrozagadkę”, Prószyński i S-ka, Warszawa 2004.

Tomasz Rakowski, Rozwiazanie „Hydrozagadki”, [w:] Popkomunizm, red.

M. Bogusławska, Z. Grębecka, LIBRON, Kraków 2010.

Jerzy Szyłak, Komiks: świat przerysowany, Słowo/Obraz Terytoria, Gdańsk 1998. Maciej Wycinek, Kapitan Żbik - fenomen propagandy PRL-u (1967-1982), [w:] Popkomunizm, red. M. Bogusławska, Z. Grębecka, LIBRON, Kraków 2010.

\section{Materiały filmowe:}

Operator was podpatrzyt (1953), „Polska Kronika Filmowa” 17/53, WFDiF. 


\section{Polish People's Republic's Superhero - on the Example of the Andrzej Kondratiuk's Movie Hydrozagadka}

In my essay I try to depict - on the basis of Andrzej Kondratiuk's movie Hydrozagadka - how superheroes from Polish People's Republic were embodying the ideal vision of the proper civilian which was advocated by the communistic system, and what were the differences between them and their Western analogues, like Superman or Batman. First of all, the order they guarded and tried to maintain was presented by propagandist agendas as a total antithesis of the Western world - full of consumption, deprivation, and a source of all imaginable evil. Though, Hydrozagadka was not only a grotesque parody of American superheroes' productions but also a mocking critique of communistic reality.

Keywords: Hydrozagadka, superhero, propaganda, Polish People's Republic, grotesque 